\title{
A.M. Potter
}

\section{Religion and the Literary Critic}

\begin{abstract}
In a recent article Jonathan Culler, condemned out of hand any use of religious terminology to define literature, seeing this as part of the destructive processes so-called "religion" has brought to American life. The article is an attempt to refute Culler by indicating, through an analysis of William Faulkner's As I Lay Dying, that an attempt to reject all religion as being destructive or quaintly anachronistic (as Culler ultimately does) seriously limits the capacity of the literary critic to explore works of literature. Evidence is brought forward to suggest that while Faulkner rejects the hypocritically pious type of religion as does Culler, he, unlike Culler, seems to be aware that religion is a much broader and deeper concept than this, exploring in an extremely positive way a type of experience universally accepted as religious, which has about it none of the qualities which Culler rejects.
\end{abstract}

There is a Peanuts cartoon which runs as follows. In the first frame Linus asks Lucy if she ever prays. Lucy responds through the next two frames with increasing belligerence: "That's kind of a personal question, isn't it? Are you trying to start an argument?" and "I SUPPOSE YOU THINK YOU'RE SOMEBODY PRETTY SMART, DON'T YOU? I SUPPOSE YOU THINK. ..." In the concluding frame Linus is sitting next to Charlie Brown, meditatively holding his blanket and sucking his thumb, and commenting "You're right ... religion is a very touchy subject!" Which brings me to Jonathan Culler's recent article entitled "Comparative Religion and the Pieties" (Culler, 1986:30-32)

In this article Culler makes a strong and often highly emotive plea for a critical stance vis a vis what he considers to be the increasingly uncritical use 
of religious terms to explicate literature, seeing this as conferring "a legitimacy on religion that contributes to its unassailability in the social and political arena" (Culler, 1986:31). With the prevalence in American society of "religious justifications for political positions" (Culler, 1986:31), and because often "religion provides an ideological legitimation for many reactionary and repressive forces in America today" (Culler, 1986:30), he suggests that "religious discourse be as much a subject of debate and critique as other ideological formations and discourses" (Culler, 1986:31). He concludes by reiterating that "we ought ... to examine the complicities of our teaching and criticism with the religious discourse that is playing an increasingly greater role in our political and cultural life" (Culler, 1986:32).

While this is obviously pointing to a particular, specific abuse of the religious experience, at other times Culler seems to extend his antipathy to religion per se, devoid of any qualification: at one stage, for example, he complains that departments of comparative literature "seldom [contain] anyone who attacks religion" and adds that "Comparatists pride themselves on their questioning of orthodoxies and ideologies, but ... characteristically hesitate to produce even the mildest critique of religion ..." (Culler, 1986:31). A little later he suggests that "we may regard religion as a curious, irrelevant survival, all the while honoring ... our most famous critics - who in their different ways are promoters of religion" (Culler, 1986:31). In each case here he uses the blanket term "religion" as if it were commonly accepted that all religious experience is precisely the same and that all religion is unacceptable.

This kind of thing seems to go beyond what could be called reasonable and balanced, into the realm of unreasoned personal prejudice, suggesting that even for a critic of international reputation like Culler, religion becomes, in Linus's words, "a very touchy subject". Of course the case for this kind of stance is easily made - provided one does not draw any fine distinctions in one's definition of "religion". Such recent incidents (at time of writing) as the spectacle of Oral Roberts claiming to be threatened by God with "recall" unless his followers donate a huge sum of money, and the Jimmy Bakker and Jimmy Swaggart sex scandals, make it seem unremarkable that a reasonably intelligent American might be dubious about so-called religion. Add this to the kind of irrational violence carried out so often in the name of religion in various parts of the world ("Protestant" versus "Catholic" sectarian violence in Ulster; terrorist attacks in the name of fundamentalist Islam, etc.), and it is fairly easy to understand that a general feeling of revulsion against all religion might well be the result.

But a thinking person - and surely the literary critic in particular should function as a thinking person - has a duty to exercise a far finer sense of distinctions than the sort of sweeping generalisation that Culler makes in the article referred to. For he seems to accept unquestioningly the definition of "religion" implicitly supplied by the behaviour and posturing of the people whose version of "religion" he sees as doing so much damage in American society, and apparently cannot see further than that. Yet, ironically, the very 
point that Culler makes about the pervasiveness of so-called "religion" as a factor in American society, its "unassailability in the social and political arena" (Culler, 1986:31), radically undermines his assertion that religion is "a curious, irrelevant survival". "Religion" it would rather seem is alive, if not necessarily well, is flourishing, even in grotesque forms, and exerts a telling influence on American - and therefore on international - life. The effect of this state of affairs may often be highly undesirable, one may even wish that "religion" were indeed "irrelevant", yet its presence and influence is undeniable.

In fact, so strong is it (whatever form it may take up), and so strong has its influence been in the past, that it is surely far wiser, instead of crying out against it with sweeping generalisations or crude slogans ("Down with the priests!" (Culler, 1986:32)) or merely rejecting its influence simply because personally one would prefer that influence not to exist, to try to come to terms with it as a real factor (even if it is often a frighteningly real factor) in human experience.

There are, in fact, eminent persons in fields other than literary studies who would claim that in some form or other the religious urge is intrinsic to human nature: the psychologists C.G. Jung and Abraham Maslow, for example, among others. This urge may take on strange forms, may be unbelievably perverted, or distorted beyond all "normal" recognition, but it is nonetheless still identifiable, a kind of "universal" that has been apparent in human affairs throughout recorded history - and a good deal further back than that. Even when overtly "religious" elements are lacking, as in the modern world after the so-called death of God, the essential urges that inspired earlier obviously "religious" processes (i.e. pertaining to some sort of worship of a superior or superhuman being) are still present:

The sacred appears to us as "numen", as "tremendum", it is the sense that there is something not produced by man and towards which the human being feels at once attraction and repulsion. It produces a sense of terror, an irresistible fascination, a feeling of inferiority and a desire for expiation and suffering. In the historical religions this confused sentiment has taken the form, in turn, of divinities more or less terrifying. But in the secular universe it has assumed, for at least a hundred years, other forms. The awesome and the fascinating no longer wear the anthropomorphic guise of the most perfect being but take on that of a Void in whose regard our aspirations are doomed to defeat. (Eco, 1986:93) (My emphasis.)

While suggesting the permanence of the "religious" urge in human nature, of course, the above quotation could be said to encourage support for Culler's contention that religion is nothing more than a totally undesirable and anachronistic feature of human society, a "confused sentiment" that needs to be done away with in whatever form it appears. Yet it also makes what to me is the important point that religion can assume a vast number of forms and manifest itself in a great number of often surprising ways. The urge is 
perpetually present in human nature: do away with one form of manifestation and it will appear in another - but it will of necessity appear. This Culler does not even attempt to acknowledge, giving the impression that he sees all religion only in terms of the hypocritically pious form which he so roundly (and probably quite rightly) condemns.

This attitude seems to lead to a number of problems: I would like to focus on one in particular in the rest of this paper. If you have disposed of all religion as objectionable, reactionary, anachronistic, or whatever, what do you, as a literary critic, do with a work of literature which, as so many of them so obviously do, not only explores the religious nature of humanity - this permanent desire on the part of human nature to acknowledge some superior "other" which it worships in some way - but seems actively to present some kind of positive attitude to one of the many forms in which religion appears?

I would like to deal with this problem by way of example, by examining the role of religion in a work of literature by a prominent American writer, the work being As I Lay Dying and the author William Faulkner.

The main thrust of the argument will be twofold. Firstly, I will attempt to show that as far as literary criticism is concerned, to throw the broadly religious baby out with the revivalist, reactionary bath-water is in fact seriously to limit one's potential awareness of the degree to which literary artists themselves are concerned with the question of the religious nature of humankind. Secondly, I will attempt to show that while in this particular work Faulkner seems to be concerned with a critique of types of the religious experience in a manner that closely parallels Culler's attitude in many ways (in particular, in the rejection of pious hypocrisy), he at the same time does not reject all "religious" experience, but rather differentiates out various types and levels of such experience, investing certain types with considerable positive energy.

Let me start with the second point first. Essential to this point is the fact that Faulkner places the most obviously "religious" statements in the mouths of the three most hypocritical individuals in the book, Anse, Whitfield the preacher, and Cora Tull. As a critic points out, "Ironically, most of the biblical language is spoken by the three most superficial and hypocritical characters in the book: Cora Tull, Whitfield, and Anse" (Rule, 1972:113). What is significant about all of them is the egotism or self-seeking nature of their so-called "religious" stance - for Anse it is a means of manipulation of others (Anse never does anything when there are other people to do things for him), for Cora Tull it is a superiority-game that she plays for her own ego-satisfaction, achieving a permanent one-up position in relation to others with her sublime confidence that she will get her just reward in heaven for her piety here on earth. Whitfield the preacher, most ostentatiously - in purely social terms - the religious man, the "man of God", breaks what is supposed 
to be "God's law" by his affair with Cora, yet hypocritically maintains his pious front. Faulkner's attitude to these characters is clear, and little more need be said about them.

They provide, however, an obvious extreme against which other types of "religious" experience in the book are measured. This experience is diametrically opposed to the kind of religiosity expressed by Whitfield, Anse and Cora Tull. It is characterised by a stress on action rather than words (i.e. it is comprised by attempts to come to terms with the issues raised by "religion" in fact or through direct experience rather than in theory), and by modes of being which for want of a better term can be defined as non-egotistical. Several characters present a range of potential response on these levels.

Superficially Dewey Dell's role seems to be similar to that of the obviously hypocritical characters. She "believes" in God insofar as He seems to her to be capable of fulfilling her own selfish aim, which is to obtain an abortion. So, when the family, instead of going to the Bundren's burial place at New Hope, where the chances of an abortion are very thin, goes on to Jefferson, where they are much better, she repeats over and over again "I believe in God, God, God, I believe in God" (Faulkner, 1972:94).

Yet on a totally instinctive, non-intellectual level - she herself is completely unaware of it - Dewey Dell fulfils a function which points essentially to Faulkner's exploration of a different type of "religious" attitude in this book. Dewey Dell is a fertility symbol, and in this way can be said to represent something that can be termed religious in a most basic sense. She is the bearer of the life-force, and represents blindly in her person a quintessential yard-stick against which life itself can be measured: one of her legs is described as "that lever which moves the world; one of that caliper which measures the length and breadth of life" (Faulkner:81). You could probably define religion in a similar way - one of the many non-scientific ways through which the human race attempts to measure and comes to terms with the universe and its own place in it. Other features of Dewey Dell's life fit in with a broadly "religious" view of life: firstly her role as a fertility symbol transcends the petty demands to ego, and secondly it links her in a very fundamental way to the whole of creation.

Jewel's commitment to the horse - and so to Addie, for whom the horse is a substitute ("Jewel's mother is a horse" (Faulkner:75)) - fulfils related functions. This commitment is equally something that transcends ego and gives to Jewel's life a "transcendent" purpose that allows Addie to speak of it - significantly - in terms that are obviously religious and would be traditionally Christian but for the fact firstly that it is difficult to reconcile Jewel with any conventional views of Christianity and secondly that Addie herself specifically rejects conventional religion totally. She uses Christian terminology as the best means to express not a particular religious dogma but the essentially "religious" terms in which she sees her son's role: "He is my cross and he will be my salvation. He will save me from the water and from 
the fire. Even though I have laid down my life, he will save me" (Faulkner:133). Cora sees this as blasphemy, but that merely reflects the limitations of her own narrowly orthodox, conventional, and ultimately very limited version of religious experience. Addie's use of Christian terminology, however, suggest that Faulkner is attempting to explore a version of religious experience - even Christian experience - in this book that goes far beyond the narrow, sectarian, and conventional.

Addie's struggle to make sense of life reflects further on the nature of the experience Faulkner is exploring in this work. Addie's disillusionment with life is to a very great extent because she sees through the emptiness of the words of people like Anse and Cora Tull and Whitfield. To her

... words go straight up in a thin line, quick and harmless, and ... doing goes along the earth, clinging to it, so that after a while the two lines are too far apart for that same person to straddle from one to the other. (Faulkner:137-8)

Her aim is to confront life fully, in terms of deeds, however terrible that may be ("I knew that living was terrible" (Faulkner:136)), not to talk uselessly about it. Yet it seems to be significant that she sees that struggle in religious terms, often using traditionally "religious" language, as in the example quoted above, to express her deepest needs. An illuminating example of this is her desire to sin in reality with Whitfield, because she can thereby make the concept sin (basic to the Christian religion, and in some form to all other religions) a reality rather than just another meaningless word (Faulkner:138).

Two things seem to come out of this book, therefore: firstly that Faulkner has precisely the same kind of attitude to hypocritical "religion" which Culler has; but at the same time, unlike Culler, he still acknowledges the reality and power of the human need which religion fulfils, and attempts to explore ways of fulfilling that need which are substantial in the sense that the method of fulfilment is as real as the need itself - i.e. matching Addie's need that deed and word are one.

The most complete fulfilment of this need is expressed through the role of Cash, who is so noticeably unverbose that he has been described as "action in search of a word" (Vickery, 1960:233). This description of Cash in fact misses the point, because as we have seen with other characters (Whitfield, Anse, Cora Tull), any fool can talk, and words are easy to use, but meaningful actions are rare. Cash is exceptional simply because he does not speak much, and does not need to search for words to justify his actions, but rather acts in a way that fulfils Addie's expectations of what deeds should be. Or, to put it another way, he has no need to seek for words, because to him his actions are the finest expression of what he is and what he believes in. This is why, as Addie lies dying, he is outside making a coffin. It is the most positive thing he can do at the time, the best way of manifesting his love for her, by responding not with pious, generalised expressions of grief but by concrete actions to her 
specific needs at the time. It is easy to see how such an action could be seen as peculiar, even perverse, but this kind of response stems from a highly conventional interpretation of what is socially acceptable and what is not.

However, what is most interesting from the point of view of this article is that Cash's behaviour can be seen as specifically religious in nature, in that it conforms to principles set out in works that are obviously claiming to present religious teachings, in the generally accepted meaning of the word "religious".

I would like to look briefly at some essential elements in Cash's role in order to make the point, which is quintessential to the argument of this paper. ${ }^{1}$ The most immediate incidents involve Cash's attitude to work, which broadens out to embrace everything he does. In a very simple way, Cash's very taciturnity can be seen to reflect his basic attitude. The Vedanta for Modern Man (Isherwood, 1952), a collection of modernised basic Vedantic teachings edited by Christopher Isherwood, makes the following point:

Why engage in idle talk, speculation, and pointless discussion? It is fruitless and leads to waste. Everyone talks but no one does anything. . . Labour hard and you will know everything in time. Exertion brings its own reward. (Isherwood:85)

Incident after incident involving Cash broadens and deepens a sense of work as a means to spiritual fulfilment. Tull, for example, describes the care with which Cash plugs up the holes bored in the coffin lid by Vardaman:

Cash is filling up the holes he bored in the top of it. He is trimming out plugs for them, one at a time, the wood wet and hard to work. He could cut up a tin can and hide the holes and nobody couldn't know the difference. Wouldn't mind anyway. I have seen him spend a hour trimming out a wedge like it was glass he was working, when he could have reached around and picked up a dozen sticks and drove them into the joint and made it do. (Faulkner:69)

Later, Darl describes how Cash cleans a splash of mud from the coffin with the same kind of infinite care:

A gout of mud, back-flung, plops onto the box. Cash leans forward and takes a tool from his box and removes it carefully. When the road crosses Whiteleaf, the willows leaning near enough, he breaks off a branch and scours at the stain with the wet leaves. (Faulkner:84)

This may only seem to be thorough workmanship or scrupulous care and nothing more, but it can equally be seen as having a potential spiritual significance in a specifically (if unconventionally) religious sense:

1. For a full discussion of Cash's function in terms of the religious concerns of the book see my "The Role of Cash in the Religious Structure of William Faulkner's As I Lay Dying" Potter: 1985). 
If you are not accurate, neat and pure in your ordinary daily activities, you cannot be so in your inner life. It is possible to judge a man's spirituality simply by watching how he sweeps a room. (Isherwood, 1952:90)

The question of attitude is paramount here, because, as has been pointed out elsewhere, attitude, rather than protestations of religiosity, is more than anything the ultimate measure of a genuinely "religious" person:

In his conversations with Waismann in 1930, Wittgenstein ... tells us that speech isn't ... essential to religion and thus it is not crucial to religion whether religious utterances can be used to make ... true or false statements or... nonsensical utterances. What is crucial here are the human attitudes and behaviour integral to religion. (Nielsen, 1982:55) ${ }^{2}$

Joseph Gold makes the same point about Faulkner's heroes as to the importance of attitude rather than the mouthing of "conventional" religious platitudes: such heroes, according to him "... are chosen because in [them] the wished-for state of mind is more readily observable ... the state of mind which they demonstrate by their living". Speaking of Dilsey in Faulkner's The Sound and the Fury Gold says "... she is fully alive in the spirit and has no concern with doctrines and dogmas and the intellectual minutiae of the religious world" (Gold, 1966:12). The same could be said of Cash.

That Cash's labours are made to have a significance beyond a simple admiration for good workmanship is suggested in the images Faulkner uses to describe Cash at work. These images are of the generation of light at the point where the labour actually takes place, where saw meets wood. The traditional connection of light with some kind of illumination or insight into truth (whether secular or spiritual) is obvious (note that Cash's labours are seen as generating a point of light in a great and ever-deepening darkness. The image is obviously a highly suggestive one):

She is looking ... at Cash stooping steadily at the board in the failing light, labouring on towards darkness and into it as though the saw illumined its own motion, board and saw engendered. (Faulkner:40)

The image is repeated later:

He saws again ... a thin thread of fire running along the edge of the saw ... (Faulkner:61)

and

The saw has not faltered, the running gleam of its pistoning edge unbroken. (Faulkner:62)

2. The reference Nielsen gives here is to Wittgenstein, 'Lectures on Ethics', 16. The emphasis is mine. 
A further potential religious significance comes out in the specific terms Faulkner uses to describe the way in which Addie receives his work. As she lies dying she calls out harshly to him, and he holds the coffin up for her to see:

He drops the saw and lifts the board for her to see, watching the window in which the face has not moved ... For a while still she looks down at him from the composite picture, neither with censure nor approbation. Then the face disappears. (Faulkner:40-41)

Every major religion stresses the importance of acting without self-interest as a means of attaining some kind of higher spiritual state, for, as Aldous Huxley explains, summarising the essential motivation for this attitude: "the more there is of self, the less there is of God" (Huxley, 1969:113). St Paul's Epistle to the Colossians 3:23-24 gives the Christian version of this attitude:

And whatsoever ye do, do it heartily, as to the Lord, and not unto men; Knowing that of the Lord ye shall receive the reward of the inheritance: for ye serve the Lord Christ.

In The Geeta, which is "to Hindus what the Bible is to Christians, the Koran to Muslims" (S.R. Gaekwar in Shri Purohit Swami, 1978:9) the same attitude to action appears:

Therefore do thy duty perfectly, without care for the results; for he who does his duty disinterestedly attains the Supreme. . . (Shri Purohit Swami, 1978:29)

and

Therefore, surrendering thy actions unto Me, thy thoughts concentrated on the Absolute, free from selfishness and without anticipation of reward, with mind devoid of excitement, begin thou to fight. (Shri Purohit Swami, 1978:30-31)

It is, of course, Addie who manifests this disinterested attitude in the passage quoted, yet Cash receives it in a similar spirit, the same one in which he carries out his work: he is concerned with doing the job properly, for its own sake, rather than with external rewards. This attitude is exemplified by the fact that he is prepared to put such infinite care into a coffin that is soon to be lowered into the ground and disappear forever from the sight of men, but it is also seen in more explicit statement later:

But it's a shame in a way. Folks seem to get away from the olden right teaching that says to drive the nails down and trim the edges well always like it was for your own use and comfort you're making it. It's like some folks has the smooth, pretty boards to build a court-house with and others don't have no more than rough lumber fitten to build a chicken coop. But it's better to build a tight chicken coop than a shoddy court-house, and 
whether they build shoddy or build well, neither because it's one or other is going to make a man feel the better nor the worse. (Faulkner:185)

Note in particular his rejection of any kind of emotional response to his labours, either positive or negative, in the last lines.

What do these references suggest? Essentially that there are ways of behaving and attitudes to life which lack all the trappings of what is conventionally seen as "religious" (which trappings in particular have bedevilled the Christian religion down through the centuries): no references to God, no talk of salvation, no connection with any church, no overt manifestations of "piety" whatsoever, no commitment to any dogma, no vision of an after-life; and yet which conform with programmes for behaviour which are explicitly religious. Couple this with the general tendency of the world's great religions to warn against false prophets and people who claim to be religious and are not, and you get at least two quite separate and mutually exclusive versions of the "religious" experience in As I lay Dying, one typified by people like Cora Tull and Whitfield and those typified at best by Addie and Cash.

Faulkner, then, could in part to be said to be making the same basic point as Culler made in the article referred to earlier: that large areas of American life are moulded by an unhealthy obsession with a type of religion that is simply a justification for a power hunger or a gigantic egoism that is destructive in itself, but often more so because it hides behind a self-righteous moralising that is often used as justification for the most stupendous crimes or hypocrisy.

But at the same time Faulkner is obviously presenting some kind of alternative view of religion, in a tradition that can be traced throughout the world's major religions. While not fulfilling any conventional notions of the concerns of religion (and this, surely, is a vital point), its manner of treatment suggests that Faulkner conceives of a broadly accepted notion of religion that is, surely, as potentially positive as the alternative is negative.

To return to our starting point, Culler's article, it seems a pity that a critic of Culler's stature should be tempted to make such one-sided and ultimately crude assessments of such a complex area of human experience as religion. Throwing the baby out with the bathwater is not something one expects of a recognised critic, yet essentially this is what Culler appears to have done. By looking only at the negative side of human religious life, he excludes simultaneously its potential for something more positive. In doing this he is, ironically, manifesting the same kind of intolerant extremism and selfrighteous assertion of his own narrow views of which those he is supposedly attacking are guilty. As Linus says in another Peanuts cartoon, "There's a lesson to be learned here somewhere ..."

\section{Bibliography}

Culler, J. 1986. "Comparative Religion and the Pieties." Profession 86. Modern Language Association of America. 
Eco, U. 1986. Travels in Hyperreality. London: Picador.

Faulkner, W. 1972. As I Lay Dying. Harmondsworth: Penguin.

Gold, J. 1966. William Faulkner: A Study of Humanism from Metaphor to Discourse. Norman: University of Oklahoma Press.

Huxley, A. 1969. The Perennial Philosophy. London: Methuen.

Isherwood, C. (ed.). 1952. Vedanta for Modern Man. London: Allen and Unwin.

Nielsen, K. 1982. Introduction to the Philosophy of Religion. London: Macmillan.

Potter, A.M. 1985. "The Role of Cash in the Religious Structure of William Faulkner's As I Lay Dying." Theoria LXV, October 1985. Pietermaritzburg: University of Natal Press.

Rule, P.C. 1972. "The Old Testament Vision in As I Lay Dying". In: J. Robert, Barth (ed.), Religious Perspectives in Faulkner's Fiction. Notre Dame and London: University of Notre Dame Press.

Swami, Shri Purohit (trans.). 1978. The Geeta. London and Boston: Faber and Faber.

Vickery, O.W. 1960. "The Dimensions of Consciousness: As I Lay Dying" In: F. J. Hoffmann and O.W. Vickery (eds.), William Faulkner: Three Decades of Criticism. Michigan State U.P. 